\title{
Combined efficacy of Azadirachta indica and Moringa oleifera leaves extract as a potential coagulant in ground water treatment
}

\author{
Pratibha Pandey ${ }^{1} \cdot$ Fahad Khan $^{1}\left[\right.$ D $\cdot$ Varish Ahmad $^{2} \cdot$ Abhimanyu Singh $^{1} \cdot$ Taniya Shamshad $^{1} \cdot$ Rashmi Mishra $^{1}$
}

Received: 5 March 2020 / Accepted: 20 June 2020 / Published online: 29 June 2020

(c) Springer Nature Switzerland AG 2020

\begin{abstract}
Azadirachta indica and Moringa oleifera plants have been reported to have strong prospective in the improvement of physiological and chemical parameters of water however very few studies have been reported towards investigating the potential of combinatorial treatment of plant extracts in water treatment. Therefore in this study, we have tried to investigate the efficacy of combined treatment of Azadirachta indica and Moringa oleifera leaves extract in hexane on ground water. We have used Jar apparatus test (flocculator) to evaluate the purification potential of combined plant extracts treatment on physiological and chemical parameter of ground water in a dose dependent manner. Our experimental findings have strongly proven the better potential of combined extract on different water quality parameters including $\mathrm{pH}$ (8.4-7.1), total dissolved solids (525-201), total hardness (253-127), turbidity (15.70-5.10), fluoride content (2.80-1.00), and Escherichia coli count (325-30) in comparison to individual extracts of Azadirachta indica and Moringa oleifera leaves extract at the similar doses $(0,25,50$, and $100 \mathrm{mg} / \mathrm{L})$. Therefore combinatorial treatment could be a strong alternate to the individual extracts in water purification.
\end{abstract}

Keywords Water treatment $\cdot$ Azadirachta indica $\cdot$ Moringa oleifera $\cdot$ Natural coagulant $\cdot$ Organic solvents $\cdot$ Ground water

\section{Introduction}

Nowadays, about 1.1 billion people are at risk due to unavailability of clean water and about $35 \%$ people in the developing countries die from water-related issues $[1,2]$. Urbanization has been one of the major causes of environmental degradation and harmful human diseases in many developing countries [3]. Unavailability of clean water to the people residing in rural areas either due to the limited awareness or their reluctance in using chemical coagulants has been leading to several human diseases and morbidity $[3,4]$. However according to a report of World Health Organization in 2012, clean water and proper sanitation can lessen death cases by about $94 \%$ [5]. Due to the expensive nature, limited unavailability and numerous side effects of chemical coagulants [6], there is a strong need to explore the potential of natural herbs for water purification in rural regions.

The possibility of use of plants that are inexpensive and easily available such as Jatropha curcas, Moringa oleifera, Strychnos potatorum, Guar gum, Azadirachta indica, Clidemia angustifolia and Hibiscus sabdariffa [7-15] to remove various contaminants from raw water will provide a inexpensive source of portable water. Amongst them, Moringa oleifera, (a tropical) has shown a wide potential in pharmaceutics, nutrition, cosmetics [16]. Several researchers have also validated its efficiency as good natural coagulant in water purification. Moringa

Pratibha Pandey and Fahad Khan have equally contributed in the manuscript.

Fahad Khan, fahadintegralian@gmail.com | 'Department of Biotechnology, Noida Institute of Engineering and Technology, 19, Knowledge Park-II, Institutional Area, Greater Noida 201306, India. ${ }^{2}$ Department of Health Information Technology, Faculty of Applied Studies, King Abdulaziz University, Jeddah 21589, Saudi Arabia. 
oleifera seed powder has exhibited good coagulation efficiency in water purification [17-20] but with few limitations including limited availability, high sludge volume $[21,22]$. Recently, we have investigated that treatment of Moringa oleifera leaves extract exhibited significant efficacy in ground water purification by improving various physiological and biological parameters [23]. Azadirachta indica has also shown strong biosorbent potential by removing several harmful toxic metals such as chromium and fluoride from waste water $[24,25]$. Although both the plants have exhibited better coagulant potential but very less has been reported about the efficacy of combinatorial treatment of Azadirachta indica and Moringa oleifera leaves extract in improving the water quality parameters. Therefore, present study is designed to perform the comparative analysis between individual extract and combined extract of both Azadirachta indica and Moringa oleifera leaves extract using hexane solvent in water treatment.

\section{Materials and methods}

\subsection{Materials}

$n$-Hexane, and other chemicals were obtained from Himedia, India. Flocculator (Jar Apparatus) was used for evaluating the coagulation efficiency of plant leaves extract in water purification.

\subsection{Ground water sample}

In present study, raw ground water samples were collected from NIET (Noida Institute of Engineering and Technology) campus Greater Noida located in Gautam Buddha Nagar District of Uttar Pradesh, India. All the ground water samples were collected in sterile, polyethylene plastic bottles and used for experimental analysis. The treated samples were then stored in deep freezers till further analysis.

\subsection{Extract preparation}

The Azadirachta indica and Moringa oleifera leaves were collected from Noida Institute of Engineering \& Technology Campus, Greater Noida. Fresh Azadirachta indica and Moringa oleifera leaves were washed with distilled water and were left for natural drying for 21 days. After natural drying, leaves were then dried in a hot air oven at $35^{\circ} \mathrm{C}$ and crushed into fine powder. Fine powder was then used for Soxhlet extraction process.

SN Applied Sciences

\subsection{Extraction process}

Azadirachta indica and Moringa oleifera leaves extract were obtained by using soxhlet extraction method with $n$-hexane solvent (1:10 ratio where 1 is plant leaves and 10 is hexane solvent). About $20 \mathrm{~g}$ of Azadirachta indica and $20 \mathrm{~g}$ of Moringa oleifera leaves were transferred into a filter paper extraction thimble and extracted with $400 \mathrm{ml} n$-hexane for $9 \mathrm{~h}$ at a maximum temperature of $70^{\circ} \mathrm{C}$ in a Soxhlet apparatus. The extraction process was continued until clear and transparent refluxing solvent was obtained $[26,27]$. After the completion of Soxhlet extraction process, $n$-hexane was removed by drying the extract for solvent evaporation and finally the obtained extract was stored into an air tight container.

\subsection{Coagulation process}

Jar apparatus test (flocculator) was used to determine the efficacy of Azadirachta indica and Moringa oleifera leaves extract in water purification as described previously [23]. Flocculator comprises of four beakers (1000 $\mathrm{ml}$ capacity) and 4 paddles (20-200 rpm) for analyzing different samples simultaneously. Coagulants (combined and individual leaves extract) were added into each beaker with varying concentrations 25,50 and $100 \mathrm{mg} / \mathrm{L}$ respectively. After treatment, the supernatant was filtered and various chemical, physiological, and biological parameters were analyzed.

\subsection{Physiochemical analysis of untreated and treated ground water sample}

Different physiochemical parameters of ground water prior and after treatment with a combination of Azadirachta indica and Moringa oleifera leaves extract were analyzed by using specific methods.

\subsubsection{Determination of $\mathrm{pH}$}

As per the guidelines of BIS, optimum $\mathrm{pH}$ of drinking water should be in the range of 6.5-8.5 (BIS, 2012) [35]. Electronic method ( $\mathrm{pH}$ meter) (Nihar Instruments, India) was used to measure $\mathrm{pH}$ variation in both treated and untreated ground water sample. $\mathrm{pH}$ meter was calibrated with standard buffer solution of base, neutral and acid before use $[28,29]$. 


\subsubsection{Determination of fluoride content}

Ground water possesses more impurity of fluoride content in comparison to surface water due to industrial effluents and fluoride bearing rocks. High fluoride content (more than $2 \mathrm{mg} / \mathrm{L}$ ) is associated with different ailments such as fluorosis [30]. Fluoride content was estimated by using Octa Aqua Test Kit (WT023, HiMedia) as per the manufacturer's instructions in both treated and untreated water sample.

\subsubsection{Determination of total hardness}

Hardness in water is mainly contributed by anions $\left(\mathrm{HCO}^{3-}\right.$, $\mathrm{SO}^{4-}, \mathrm{Cl}^{-}, \mathrm{NO}^{3-}$ and $\left.\mathrm{SiO}^{3-}\right)$ and cations $\left(\mathrm{Ca}^{2+}, \mathrm{Fe}^{2+}, \mathrm{Mg}^{2+}\right.$, $\mathrm{Mn}^{2+}$ and $\mathrm{Sr}^{2+}$ ) [31]. Hardness concentration more than $200 \mathrm{mg} / \mathrm{L}$ has been associated with scale deposition in ground water (WHO 2003). Total hardness in both treated and untreated ground water sample was evaluated by using Octa Aqua Test Kit (WT023, Hi Media) according to the manufacturer's protocol.

\subsubsection{Determination of total dissolved solids or TDS}

Several studies have reported that high concentration of total dissolved solids (i.e. more than $500 \mathrm{mg} / \mathrm{L}$ ) leads to numerous gastrointestinal disorders and also decrease palatability [32]. TDS level in both treated and untreated water sample was measured by TDS Meter (Hanna Instruments).

\subsubsection{Determination of turbidity}

According to WHO, 2012 [33] the acceptable limit of turbidity in drinking water is 6 NTU. Turbidity in water increases due to the presence of particulate matter that results either due to inappropriate filtration or sediment re suspension. Turbidity in untreated and treated ground water sample was determined by Octa Aqua Test Kit (WT023, HiMedia).

\subsection{Total Escherichia coli analysis}

In our study, E. coli count analysis was done according to the protocol described by previously [23]. In brief, ground water samples were collected from every individual jar (both treated and untreated sample) and diluted with $0.1 \%$ sterile peptone water (ranging from $10^{-1}, 10^{-2}$ and $\left.10^{-3}\right)$. Then, both the treated and untreated ground water samples were filtered using Whatman membrane filters $(0.45 \mu \mathrm{m})$ on petri dishes containing membrane lactose glucuronide agar (MLGA) followed by incubation at $37^{\circ} \mathrm{C}$ for $24 \mathrm{~h}$. Finally the $E$. coli were quantified as green colonies and were estimated by a count/100 $\mathrm{ml}$ [34].

\subsection{Statistical analysis}

All the experiments were performed in triplicates and data were represented as the mean \pm SE of three individual experiments.

\section{Results and discussion}

\subsection{Individual and combinatorial effect of leaves extract on $\mathrm{pH}$}

As per WHO guidelines, 2012, the acceptable value of $\mathrm{pH}$ in drinking water should be between 7 and 8 [33]. $\mathrm{pH}$ (negative logarithm of Hydrogen ion concentration) can be referred as the significant parameter for testing the quality of drinking water. Treatments with both individual as well as combined doses of Azadirachta indica and Moringa oleifera leaves extract have shown effective reduction in $\mathrm{pH}$ of water sample in a dose dependent manner in accordance with previous findings [35-40]. However combined leaves extract of both the plants has shown better $\mathrm{pH}$ reduction (8.4-7.1) at a lower dose in comparison to individual extracts of Azadirachta indica (8.4-7.5) and Moringa oleifera (8.4-7.4) (Fig. 1). Thus it can be clearly concluded that combined treatment increased the efficacy of plant extracts on $\mathrm{pH}$ reduction at a lower dose and therefore should be strongly preferred over individual plant extract.

\section{Moringa+Neem $\mathbf{0}$ Neem 目 Moringa}

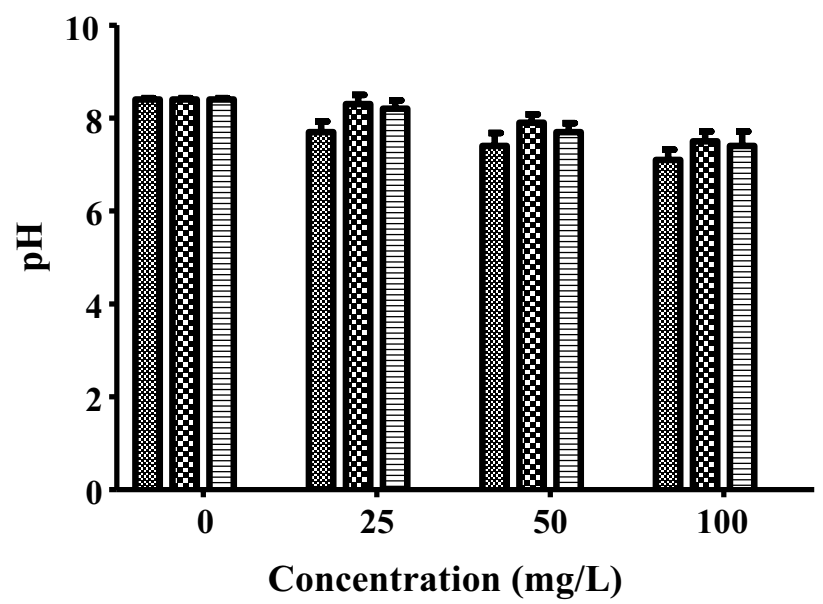

Fig. 1 Effect of individual and combinatorial treatment of leaves extract (Moringa + Neem, Neem and Moringa) on pH of water sample at a concentration of $25-100 \mathrm{mg} / \mathrm{L}$. All the experiments were performed in triplicates and represented as mean \pm SEM 


\subsection{Individual and combinatorial effect of leaves extract on TDS}

Increased concentration of total dissolved solids is responsible for decreasing the availability of water (for different purposes including drinking, industrial and irrigation) by increasing the density of water. Dissolved solids also reduce the solubility of dissolved gases present in water thereby hampering the water quality. Further, the efficacies of both plants leaves extract were determined for the TDS removal. By definition, TDS (total dissolved solid) can be defined as the sum amount of both organic and inorganic substances found in numerous forms from molecular, ionized to micro-granular in water [28]. These organic or inorganic contaminants are present in water due to both artificial such as urban run-off, industrial wastewater, sewage, chemicals and natural resources. In Fig. 2 , it can be seen that Azadirachta indica leaves extract have not shown significant effect on TDS removal at the dose of $25 \mathrm{mg} / \mathrm{L}$ whereas moringa leaves (525-279 $\mathrm{mg} / \mathrm{L}$ ) and combined leaves extract (525-201 mg/L) have shown significant reduction in a dose dependent manner (Fig. 2). Results strongly indicated that combinatorial treatment has shown better efficacy than both the individual extracts.

\subsection{Individual and combinatorial effect of leaves extract on total hardness analysis}

Combinatorial treatment of both plant leaves extract has depicted more significant reduction in total hardness of water sample (Fig. 3) as compared to individual extracts

\section{Moringa+Neem 8 Neem}

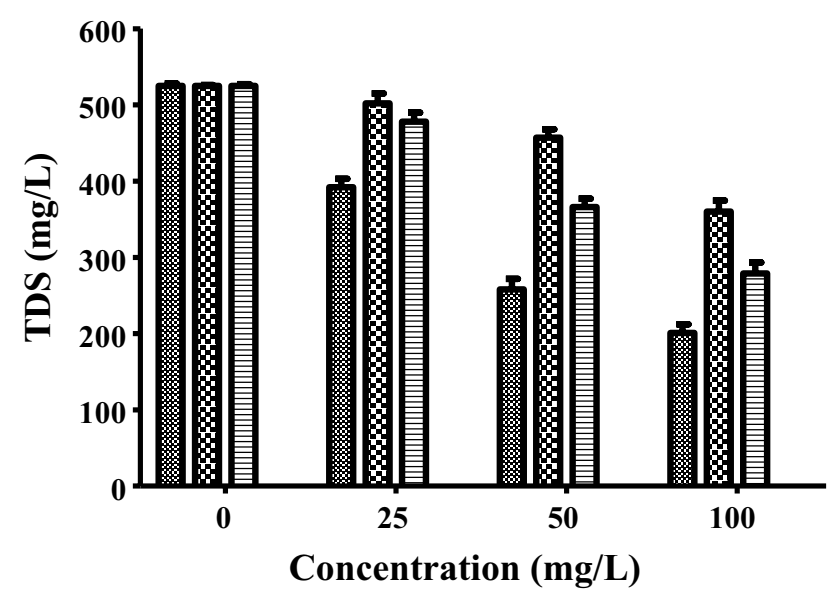

Fig. 2 Effect of individual and combinatorial treatment of leaves extract (Moringa + Neem, Neem and Moringa) on TDS (Total dissolved solids) of water sample at a concentration of $25-100 \mathrm{mg} / \mathrm{L}$. All the experiments were performed in triplicates and represented as mean $\pm \mathrm{SEM}$

SN Applied Sciences

\section{Moringa+Neem $\mathbf{0}$ Neem 目 Moringa}

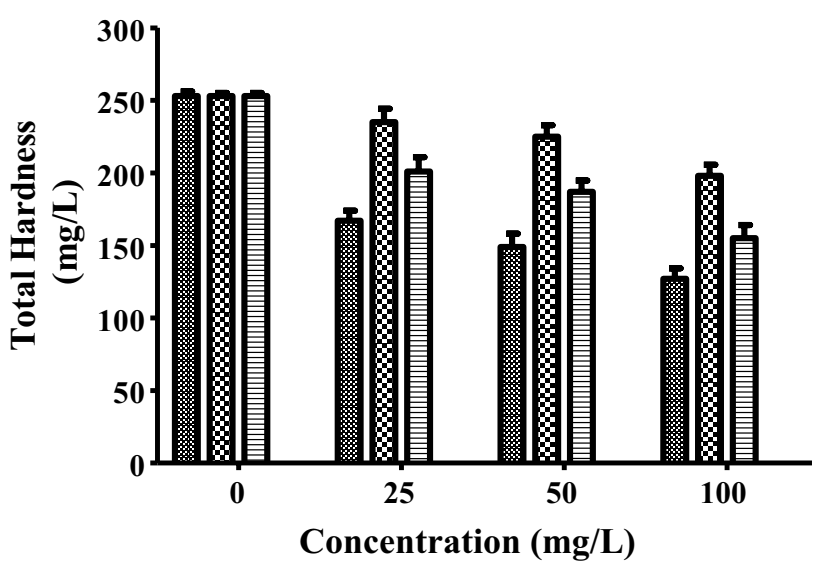

Fig. 3 Effect of individual and combinatorial treatment of leaves extract (Moringa +Neem, Neem and Moringa) on total Hardness of water sample at a concentration of 25-100 mg/L. All the experiments were performed in triplicates and represented as mean \pm SEM

of Azadirachta indica and Moringa oleifera as depicted in earlier reports [41, 42]. Although both individual and combined extracts have shown significant decrease in total hardness of ground water in a dose dependent manner, combinatorial treatment (253-127 mg/L) has shown more reduction in the total hardness at the same dose in comparison to the individual extracts of Moringa (253-155 mg/L) and Azadirachta indica leaves (253-198 mg/L). Thus it can be concluded that combined extract treatment has improved the efficacy by combining the potential of both the individual extracts and therefore should be preferred over individual extract for showing better reduction efficiency in water treatment.

\subsection{Individual and combinatorial effect of leaves extract on turbidity}

After treatment with both individual and combined leaves extract of Azadirachta indica and Moringa oleifera, the turbidity was reduced significantly in dose dependent manner (Fig. 4). Moringa extract (15.7-5.10 NTU) has shown better efficacy in turbidity removal than Azadirachta indica leaves (15.7-6.8 NTU) However extracts in combination (15.7-5.10 NTU) has depicted better reduction in turbidity at the same dose of individual extracts of Azadirachta indica and Moringa oleifera thereby indicating the better potential of combined extract. 


\section{Moringa+Neem 8 Neem 目 Moringa}

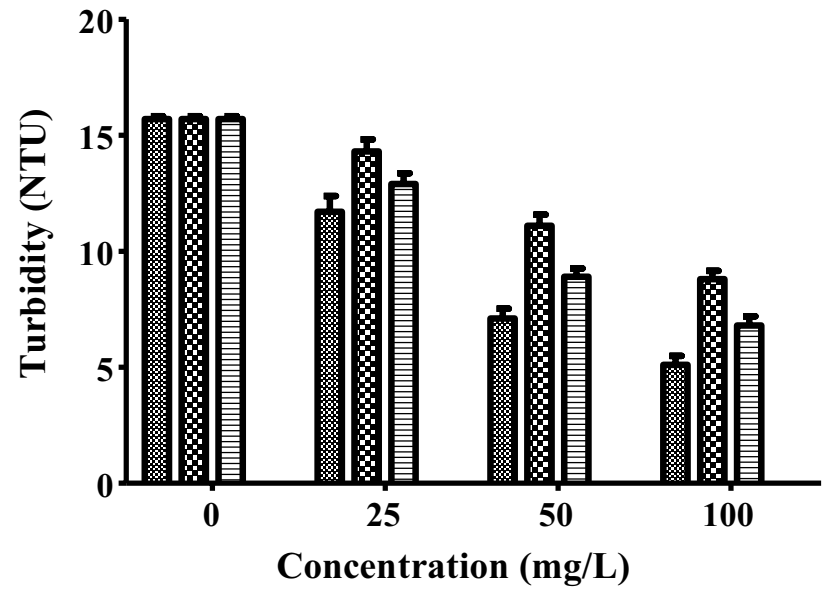

Fig. 4 Effect of individual and combinatorial treatment of leaves extract (Moringa + Neem, Neem and Moringa) on Turbidity of water sample at a concentration of $25-100 \mathrm{mg} / \mathrm{L}$. All the experiments were performed in triplicates and represented as mean \pm SEM

\subsection{Individual and combinatorial effect of leaves extract on fluoride}

High fluoride content has been associated with several health related issues in humans such as skeletal or dental fluorosis and several studies have reported the presence of excess fluoride in groundwater of many developing countries [43]. Both the combined as well as individual extract treatment has shown significant reduction in fluoride content in a concentration dependent manner. Azadirachta indica leaves has shown significant reduction at the dose of $100 \mathrm{mg} / \mathrm{L}(1.98 \mathrm{mg} / \mathrm{L})$ whereas Moringa oleifera extract has shown significant reduction at the dose of $50 \mathrm{mg} / \mathrm{mL}$ $(2.40 \mathrm{mg} / \mathrm{L})$ and $100 \mathrm{mg} / \mathrm{L}(1.50 \mathrm{mg} / \mathrm{L})$. However, combinatorial treatment has shown the better reduction of fluoride content (2.8-1.00 $\mathrm{mg} / \mathrm{L})$ at the similar doses of individual extracts of both plants (Fig. 5). Thus it can be concluded that combinatorial treatment has enhanced potential in fluoride removal than the individual extracts in corroboration with our previous findings.

\subsection{Individual and combinatorial effect of leaves extract on $E$. coli}

In this study, effect of leaves extracts of Azadirachta indica and Moringa oleifera plants either in alone or in combination on biological contaminant i.e. E. coli in water sample was determined. Azadirachta indica and Moringa oleifera has been known for its anti bacterial and antifungal potential therefore we have evaluated the effect on $E$. coli count in treated water sample. It can be seen from the Fig. 6 that

\section{Moringa+Neem 8 Neem 自 Moringa}

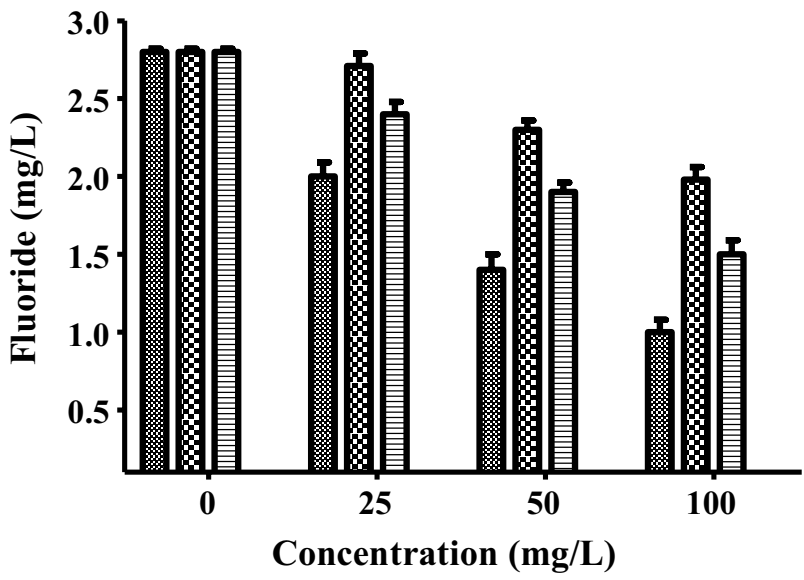

Fig. 5 Effect of individual and combinatorial treatment of leaves extract (Moringa +Neem, Neem and Moringa) on Fluoride content of water sample at a concentration of $25-100 \mathrm{mg} / \mathrm{L}$. All the experiments were performed in triplicates and represented as mean \pm SEM

Azadirachta indica has shown better reduction in E. coli count than Moringa oleifera leaves extract. However after treatment of ground water sample with combined extract of Azadirachta indica and Moringa oleifera, there has been a more significant reduction in E. coli count than the individual extracts.

Several reports have proven the antibacterial potential of both Azadirachta indica and Moringa oleifera leaves against the E. coli strains [43-45]. Our previous study

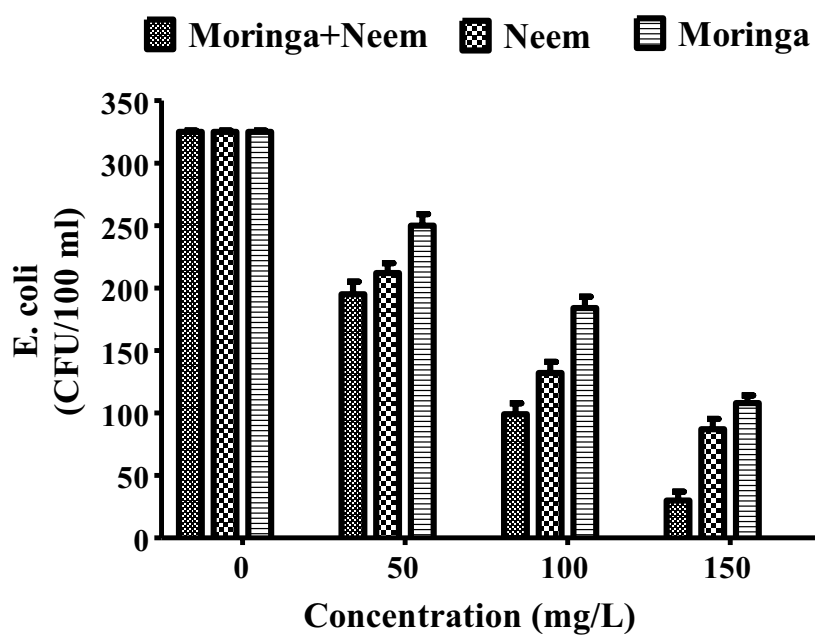

Fig. 6 Effect of individual and combinatorial treatment of leaves extract (Moringa + Neem, Neem and Moringa) on E. coli count of water sample at a concentration of $25-100 \mathrm{mg} / \mathrm{L}$. All the experiments were performed in triplicates and represented as mean \pm SEM 
has also showed that Moringa oleifera leaf extract has shown significant antibacterial potential in water treatment process [23]. In addition, present study has revealed that combined extract of Azadirachta indica and Moringa oleifera leaves has depicted enhanced efficiency than the individual extracts. Through these results it can be hypothesized that the probable mechanism behind this antimicrobial elimination in treated ground water sample could be due to coagulation, precipitation and disruption of cell membrane in accordance with the previous findings [46-50]. Thus, after the treatment of ground water sample with natural coagulant, the cationic protein present in the Azadirachta indica and Moringa oleifera leaves extract interacted with negatively charged particle found in ground water sample. These interactions then resulted in precipitate development of particulate matter by the disturbance in the association of suspended particles. Thus it can be concluded that combined treatment of Azadirachta indica and Moringa oleifera leaves extract has better purification potential than the individual extracts in water treatment processes.

\section{Conclusion}

People residing in rural or tribal areas have been using the water from any sources without any treatment due to their limited awareness about the impurities present in water and their associated side effects. They are also reluctant in using any chemical coagulant for water purification due to their higher cost. Therefore there is a strong need to find a natural alternative for the people of rural areas. Plants with medicinal properties including Azadirachta indica and Moringa oleifera leaves used in this study can be effectively used as a strong natural coagulant for water purification. Using these extracts, not only harmful and pathogenic microbes from water can be removed but their quality parameters can also be improved with minimal or no side effects and thus could provide water safe for the people of rural areas. Coagulation potential of both individual and combined extract of Azadirachta indica and Moringa oleifera leaves has been exploited in our study to elucidate a cost effective method with minimal side effects. Experimental results showed that treatment with combined extract of Azadirachta indica and Moringa oleifera leaves extract can greatly improve both the physiological parameters ( $\mathrm{pH}$, turbidity, total dissolved solid) and chemical parameter (fluoride content) of ground water at the similar dose in comparison to individual extract. Furthermore combinatorial treatment has also exhibited significant antibacterial efficacy than the individual extract of Azadirachta indica and Moringa oleifera leaves extract. Therefore, this study strongly suggested that combined treatment of leaves extract obtained in hexane solvent could be a potent coagulant with less side effects and cost. Further studies are still needed to develop this concept into a cost efficient technique for providing safe water to the people residing in rural areas of developing countries.

Acknowledgements We would like to thank the management of Noida Institute of Engineering \& Technology, Greater Noida (NIET) for their support in terms of Lab and other infrastructure. Also we would like to thank Dr. A. P. J. Abdul Kalam Technical University, Lucknow for providing the fund for procuring chemicals and reagents.

Funding This study was funded by project grant under "Collaborative research and Innovation Program (CRIP)" funding through TEQIP-III of Dr. A. P. J. Abdul Kalam Technical University (AKTU/DEAN-PGSR/2019/ CRIP/26).

Data Availability The data that support the findings of this study are available on request from the corresponding author. The data are not publicly available due to privacy or ethical restrictions.

\section{Compliance with ethical standards}

Conflict of interest All the authors associated with this manuscript declare that there is no conflict of interest.

\section{References}

1. Goyal AK, Johal ES, Rath G (2011) Nanotechnology for water treatment. Curr Nanosci 7(4):640-654

2. Vemula SR, Kumar RN, Polasa K (2012) Foodborne diseases in India-a review. Br Food J 114:661-680

3. Rashid H, Manzoor MM, Mukhtar S (2018) Urbanization and its effects on water resources: an exploratory analysis. Asian J Water Environ Pollut 15(1):67-74

4. Gambhir RS, Kapoor V, Nirola A, Sohi R, Bansal V (2012) Water pollution: impact of pollutants and new promising techniques in purification process. J Hum Ecol 37(2):103-109

5. Flanagan SV, Johnston RB, Zheng Y (2012) Arsenic in tube well water in Bangladesh: health and economic impacts and implications for arsenic mitigation. Bull World Health Org 90:839-846

6. Crini G, Lichtfouse E (2019) Advantages and disadvantages of techniques used for wastewater treatment. Environ Chem Lett 17(1):145-155

7. Abidin ZZ, Shamsudin NSM, Madehi N, Sobri S (2013) Optimisation of a method to extract the active coagulant agent from Jatropha curcas seeds for use in turbidity removal. Ind Crops Prod 41:319-323

8. Pritchard M, Craven T, Mkandawire T, Edmondson AS, O'neill JG (2010) A study of the parameters affecting the effectiveness of Moringa oleifera in drinking water purification. Phys Chem Earth Parts A/B/C 35(13-14):791-797

9. Al-Anizi AA, Hellyer MT, Zhang D (2014) Toxicity assessment and modelling of Moringa oleifera seeds in water purification by whole cell bioreporter. Water Res 56:77-87

10. Thakur S, Sharma B, Verma A, Chaudhary J, Tamulevicius S, Thakur VK (2018) Recent approaches in guar gum hydrogel synthesis for water purification. Int J Polym Anal Charact 23(7):621-632 
11. Somani S, Ingole N, Patil S (2011) Performance evaluation of natural herbs for antibacterial activity in water purification. Int J Eng Sci Technol 3(9):7170-7174

12. Pritchard M, Craven T, Mkandawire T, Edmondson AS, O'neill JG (2010) A comparison between Moringa oleifera and chemical coagulants in the purification of drinking water-an alternative sustainable solution for developing countries. Phys Chem Earth Parts A/B/C 35(13-14):798-805

13. Nwaiwu NE, Mshelia F, Raufu IA (2012) Antimicrobial activities of crude extracts of Moringa oleifera, Hibiscus sabdariffa and Hibiscus esculentus seeds against some enterobacteria. J Appl Phytotechnol Environ Sanit 1(1):11-16

14. Jayalakshmi G, Saritha V, Dwarapureddi BK (2017) A review on native plant based coagulants for water purification. Int J Appl Environ Sci 12(3):469-487

15. Saif MMS, Kumar NS, Prasad MNV (2012) Binding of cadmium to Strychnos potatorum seed proteins in aqueous solution: adsorption kinetics and relevance to water purification. Colloids Surf B 94:73-79

16. Yin CY (2010) Emerging usage of plant-based coagulants for water and wastewater treatment. Process Biochem 45(9):1437-1444

17. Shan TC, Al Matar M, Makky EA, Ali EN (2017) The use of Moringa oleifera seed as a natural coagulant for wastewater treatment and heavy metals removal. Appl Water Sci 7(3):1369-1376

18. Vunain E, Masoamphambe EF, Mpeketula PMG, Monjerezi M, Etale A (2019) Evaluation of coagulating efficiency and water borne pathogens reduction capacity of Moringa oleifera seed powder for treatment of domestic wastewater from Zomba, Malawi. J Environ Chem Eng 7(3):103118

19. Okuda T, Ali EN (2019) Application of Moringa oleifera plant in water treatment. In: Bui XT, Chiemchaisri C, Fujioka T, Varjani S (eds) Water and wastewater treatment technologies. Energy, Environment, and Sustainability. Springer, Singapore, pp 63-79

20. Das PK, Di Sante D, Vobornik I, Fujii J, Okuda T, Bruyer E et al (2019) Author Correction: layer-dependent quantum cooperation of electron and hole states in the anomalous semimetal WTe 2. Nat Commun 10(1):1

21. Ghebremichael K, Abaliwano J, Amy G (2009) Combined natural organic and synthetic inorganic coagulants for surface water treatment. J Water Supply Res Technol AQUA 58(4):267-276

22. Beltrán-Heredia J, Sánchez-Martín J, Munoz-Serrano A, Peres JA (2012) Towards overcoming TOC increase in wastewater treated with Moringa oleifera seed extract. Chem Eng J 188:40-46

23. Pandey P, Khan F, Mishra R, Singh SK (2020) Elucidation of the potential of Moringa oleifera leaves extract as a potent alternate to the chemical coagulant in water treatment process. Water Environ Res 92(7):1051-1056

24. Vinodhini V, Das N (2010) Packed bed column studies on $\mathrm{Cr}(\mathrm{Vl})$ removal from tannery wastewater by neem sawdust. Desalination 264(1-2):9-14

25. Manna S, Saha P, Roy D, Adhikari B, Das P (2018) Fixed bed column study for water defluoridation using neem oil-phenolic resin treated plant bio-sorbent. J Environ Manag 212:424-432

26. Prathna TC (2019) Biosynthesized Nanoparticles for Water Treatment. In: Karthik L, Vishnu Kirthi A, Ranjan S, Mohana Srinivasan $\checkmark$ (eds) Biological synthesis of nanoparticles and their applications. CRC Press, pp 227-232

27. De Castro ML, Priego-Capote F (2010) Soxhlet extraction: past and present panacea. J Chromatogr A 1217(16):2383-2389

28. Da Porto C, Decorti D, Natolino A (2016) Microwave pretreatment of Moringa oleifera seed: effect on oil obtained by pilot-scale supercritical carbon dioxide extraction and Soxhlet apparatus. J Supercrit Fluids 107:38-43

29. Islam A, Guha AK (2013) Removal of pH, TDS and color from textile effluent by using coagulants and aquatic/non aquatic plants as adsorbents. Resour Environ 3(5):101-114

30. Kumar M, Puri A (2012) A review of permissible limits of drinking water. Indian J Occup Environ Med 16(1):40

31. Soni R, Modi S (2013) Removal of fluoride from drinking water using red mud. Int J Sci Technol Res 2(10):120-122

32. Saleem M, Hussain A, Mahmood G (2016) Analysis of groundwater quality using water quality index: a case study of greater Noida (Region), Uttar Pradesh (UP), India. Cogent Eng 3(1):1237927

33. WHO (2012) Guidelines for drinking water, recommendations, world health organizations. WHO, Geneva

34. Pritchard M, Mkandawire T, Edmondson A, O'neill. JG, Kululanga $G$ (2009) Potential of using plant extracts for purification of shallow well water in Malawi. Phys Chem Earth Parts $A / B / C$ 34(13-16):799-805

35. BIS (2012) Drinking water specification IS: 10500:2012. Bureau of Indian Standards, New Delhi

36. Vinayagam R, Selvaraj $R$, Arivalagan $P$, Varadavenkatesan $T$ (2020) Synthesis, characterization and photocatalytic dye degradation capability of Calliandra haematocephala-mediated zinc oxide nanoflowers. J Photochem Photobiol, B 203:111760

37. Mangale Sapana M, Chonde Sonal G, Raut PD (2012) Use of Moringa oleifera (drumstick) seed as natural absorbent and an antimicrobial agent for ground water treatment. Res J Rec Sci 1(3):31-40

38. Baptista ATA, Silva MO, Gomes RG, Bergamasco R, Vieira MF, Vieira AMS (2017) Protein fractionation of seeds of Moringa oleifera lam and its application in superficial water treatment. Sep Purif Technol 180:114-124

39. Zaid AQ, Ghazali SB, Mutamim NSA, Olalere OA (2019) Experimental optimization of Moringa oleifera seed powder as biocoagulants in water treatment process. SN Appl Sci 1(5):504

40. Sulaiman $M$, Zhigila DA, Mohammed K, Umar DM, Aliyu B, Abd Manan F (2017) Moringa oleifera seed as alternative natural coagulant for potential application in water treatment: a review. J Adv Rev Sci Res 30(1):1-11

41. Chethana M, Sorokhaibam LG, Bhandari VM, Raja S, Ranade VV (2016) Green approach to dye wastewater treatment using biocoagulants. ACS Sustain Chem Eng 4(5):2495-2507

42. Nouhi S, Kwaambwa HM, Gutfreund P, Rennie AR (2019) Comparative study of flocculation and adsorption behaviour of water treatment proteins from Moringa peregrina and Moringa oleifera seeds. Sci Rep 9(1):1-9

43. Ali S, Thakur SK, Sarkar A, Shekhar S (2016) Worldwide contamination of water by fluoride. Environ Chem Lett 14(3):291-315

44. Paray AR, Bhakat M, Mohanty TK, Behare P, Lone SA, Parry UR et al (2018) Antimicrobial activity of crude aqueous extracts of Moringa oleifera, Azadirachta indica, Carica papaya, Tinospora cordifolia and Curcuma longa against certain bacterial pathogens. J Pharmacogn Phytochem 7(4):984-994

45. Kumari R, Dubey RC, Kumar S (2018) Antibacterial efficacy of acetone soluble oil of Azadirachta indica on some bacterial strains. J Plant Pathol Microbiol 9(447):2

46. Ravikumar S, Gokulakrishnan R, Boomi $P$ (2012) In vitro antibacterial activity of the metal oxide nanoparticles against urinary tract infectious bacterial pathogens. Asian Pac J Trop Dis 2(2):85-89

47. Zhou H, Smith DW (2002) Advanced technologies in water and wastewater treatment. J Environ Eng Sci 1(4):247-264

48. Dash A, Ahmed MT, Selvaraj R (2019) Mesoporous magnetite nanoparticles synthesis using the Peltophorum pterocarpum 
pod extract, their antibacterial efficacy against pathogens and ability to remove a pollutant dye. J Mol Struct 1178:268-273

49. Varadavenkatesan T, Selvaraj R, Vinayagam R (2019) Dye degradation and antibacterial activity of green synthesized silver nanoparticles using Ipomoea digitata Linn. flower extract. Int J Environ Sci Technol 16(5):2395-2404

50. Anchan S, Pai S, Sridevi H, Varadavenkatesan T, Vinayagam R, Selvaraj R (2019) Biogenic synthesis of ferric oxide nanoparticles using the leaf extract of Peltophorum pterocarpum and their catalytic dye degradation potential. Biocatal Agric Biotechnol 20:101251

Publisher's Note Springer Nature remains neutral with regard to jurisdictional claims in published maps and institutional affiliations. 